\section{hommes}

\section{Hommes \& migrations}

Revue française de référence sur les dynamiques

migratoires

\section{$1291 \mid 2011$}

\section{Diasporas sri lankaises}

\title{
Si tu meurs, je te tue
}

Film franco-kurde de Hiner Saleem

\section{André Videau}

\section{Q OpenEdition \\ 1 Journals}

\section{Édition électronique}

URL : http://journals.openedition.org/hommesmigrations/703

DOI : 10.4000/hommesmigrations.703

ISSN : 2262-3353

\section{Éditeur}

Musée national de l'histoire de l'immigration

\section{Édition imprimée}

Date de publication : 1 mai 2011

Pagination : 156

ISSN : 1142-852X

\section{Référence électronique}

André Videau, «Si tu meurs, je te tue », Hommes \& migrations [En ligne], 1291 | 2011, mis en ligne le 29 mai 2013, consulté le 22 septembre 2020. URL : http://journals.openedition.org/hommesmigrations/ 703 ; DOI : https://doi.org/10.4000/hommesmigrations.703

Ce document a été généré automatiquement le 22 septembre 2020.

Tous droits réservés 


\title{
Si tu meurs, je te tue
}

\author{
Film franco-kurde de Hiner Saleem
}

\section{André Videau}

1 Tout ce que l'on sait de Philippe, c'est qu'il sort de prison (Jonathan Zaccaï, solide gaillard qui n'a pas l'air capable d'avoir fait du mal à une mouche). D'ailleurs dans son quartier du $\mathrm{x}^{\mathrm{e}}$ arrondissement de Paris (rue du Faubourg-Saint-Denis), il a retrouvé des habitudes paisibles d'avant l'incarcération. Son modeste appartement conservé par une logeuse, pianiste un peu fofolle (Mylène Demongeot, qui sait émouvoir à chacune de ses apparitions). Des petits boulots qui laissent le champ libre. Des comptoirs de bar où l'on peut échanger des propos sans suite avec des habitués ou des inconnus devant une consommation ou un œuf dur. Relationnellement très importants, les œufs durs! C'est ainsi que Philippe va se lier avec Avdal (Billey Demirtas), beau mec un peu paumé, querelleur et pas trop regardant sur la morale. Nous avons aussi intérêt à faire très vite connaissance avec lui car il va disparaitre dès le début de l'action. Le metteur en scène aime ces tours de passe-passe et ces volte-face. Avdal est venu à Paris pourchasser un complice de Saddam Hussein. Il meurt subitement dans les transports en commun alors qu'il se rendait à un rendez-vous galant. Pour Philippe c'est l'engrenage. Il n'a que quelques jours pour éviter la fosse commune au cadavre anonyme, comme lui rappelle un digne officiant des pompes funèbres (Maurice Bénichou, exemplaire). Le voilà propulsé parmi les Kurdes de la diaspora, une collection de machos truculents et balourds, émoustillés par l'arrivée de la fiancée du défunt. L'éblouissante Siba n'est pas qu'une veuve éplorée. C'est une fervente militante de l'émancipation féminine. C'est surtout Golshifteh Farahani, comédienne iranienne rebelle qui refusa de porter le voile pour monter les marches du Festival de Cannes. Vous devinez sans peine le happy end. Hiner Saleem nous offre, après Vive la mariée... et la libération du Kurdistan, Vodka Lemon, Kilomètre zéro et Passeurs de rêves, un nouveau film savoureux en miroir facétieux et affectueux de sa propre communauté. 